Nat. Hazards Earth Syst. Sci. Discuss., https://doi.org/10.5194/nhess-2017-377

Manuscript under review for journal Nat. Hazards Earth Syst. Sci.

Discussion started: 21 November 2017

(c) Author(s) 2017. CC BY 4.0 License.

(c) (P)
Natural Hazards

and Earth System

Sciences

Discussions

\title{
Characterization agricultural vulnerability to drought in the Northeast of Brazil
}

Bruce K. N. Silva ${ }^{1}$, Paulo S. Lucio ${ }^{1}$, Cláudio M. S. Silva ${ }^{1}$, Maria H. C. Spyrides ${ }^{1}$, Madson T. Silva ${ }^{2}$, Lara M. B. Andrade ${ }^{1}$

5 'Programa de Pós-graduação em Ciências Climáticas, Universidade Federal do Rio Grande do Norte-UFRN, Campus Lagoa Nova, 59072-970, Natal-RN, Brasil.

${ }^{2}$ Unidade Acadêmica de Ciências Atmosféricas, Universidade Federal de Campina Grande-UFCG, Rua: Aprígio Veloso, 882, 58429-900, Campina Grande-PB, Brasil.

Correspondence to: Bruce K. N. Silva (brucekellys@ hotmail.com)

10 Abstract. The main objective was to create an indicator of agricultural vulnerability to drought in the Northeast of Brazil (NEB). The data used for precipitation belong to ANA (Agência Nacional das Águas) considering the climatological norm from 1979-2008. Data on agricultural productivity and demographic characteristics were obtained in the agricultural census of IBGE (Brazilian Institute of Geography and Statistics) in 2006 and, finally, data on natural disasters in the period 1991-2010 with CEPED (Centro de Estudos e Pesquisas em Engenharia e Defesa Civil). The Multivariate Statistical Analysis Factorial

15 technique allowed to reduce the number of variables and to estimate a model of the sensitivity component that reproduced $42 \%$ of the original variance, besides the factors trying to represent the productive dynamics of the NEB. The results show that the Southern NEB presented the highest degree of agricultural vulnerability $(17,81-121,44)$ in the 2000 census, when compared to the census of 2010. In the Southwest it is observed that a part of the semi-arid region presented a moderate degree $(0,74-$ 1,08 ) and much higher in extension when compared to the 2000 census, evidencing that exposure to drought does not directly

20 influence the agricultural sensitivity in the most productive areas of the region. The adaptive capacity factor presented significant results for the composition of the indicator of agricultural vulnerability, mainly in the semi-arid region that varied from $(0,71-5,42)$. In this way, it is concluded that, between the census, the southern and central part of the NEB reduced agricultural vulnerability, but the region should benefit from early warning systems as well as the development and adoption of natural resources and technology management, with the objective of educating producers about the potential impacts of extreme events.

\section{Introduction}

The Northeast region of Brazil (NEB) covers an area of 1,554,291.61 $\mathrm{km}^{2}$ which represents approximately $18 \%$ of the country possessing high variability of precipitation timeline. The performance of different meteorological systems and the deficiency

30 of public policies in managing water resources or severe weather warnings, which favors the occurrence of economic losses and human lives in the region. The effects of weather and climate phenomena have negative impacts on agricultural production, especially small producers Luers et al.,(2003);Silva and Lucio, (2014), in energy production and water supply due to the 
Nat. Hazards Earth Syst. Sci. Discuss., https://doi.org/10.5194/nhess-2017-377

Manuscript under review for journal Nat. Hazards Earth Syst. Sci.

Discussion started: 21 November 2017

(c) Author(s) 2017. CC BY 4.0 License.

shortage of reservoirs Tubi et al.,(2012), as well as impacts on health, leading to endemic outbreaks such as dengue and problems linked to lack or poor water quality Tanser et al., (2003). An extreme precipitation event is considered natural disaster when adversely affects the ecological, economic, social and cultural systems of a region (Castro et al., 2003). In the scientific literature, a well explored theme is the drought, its impacts and methodologies to predict this phenomenon (Zhang and Yongfu,

5 2003). For Lee, (2014) most research emphasizes the disaster as a risk exposure to certain phenomenon and evaluation of biophysical vulnerability. However, in recent decades, a growing number of research disagrees with this approach, considering the disaster as a means of social construction (Cardona, 2003; Simelton et al., 2009; Sánchez-Cortés and Chavero, 2010; Antwi-Agyei et al., 2012). In these studies, it is shown that social factors amplify the effects of disasters related to extremes events. Therefore, these factors can serve as proxies of social inequalities, such as poverty, education, level of infrastructure 10 among others, featuring social vulnerability (Lee, 2014).

Thus, researchers and civil society realized the real need for more effective policies to combat and coexistence with these extreme precipitation phenomena. Measures not only mitigation but also developing of preparedness plan that encompasses forecasting, monitoring, prevention, vulnerability assessment of the sectors and regions, as well as assistance and response to drought impacts. In this context, the concept of the agricultural vulnerability is present in some countries: Mexico (Luers et 15 al., 2003); Ahmed et al., 2009); Ghana (Antwi-Agyei et al., 2012); and China (Simelton et al., 2009); (Simelton et al., 2009). In addition to different areas of knowledge: social sciences Ahmed et al., (2009); economy Ibarrarán et al., (2007); health Barata and Confalonieri, (2011); meteorology and climatology (Karim and Mimura, 2008; Nelson et al., 2010a). Despite its frequent use in recent years, the concept of vulnerability is rarely converted into analytical measurements that can be used to advise policy interventions and assess their impact. The demand for research that prioritizes adaptation policy now has greater

20 importance in society in the face of extreme climate threat (Ford et al., 2006).

In addition, advances in theoretical and methodological discussions in vulnerable gave room for both approaches, the relationship "human-environment" and the ratio "risk-hazard". The first concerns to the study of environmental processes on a global scale, especially climate change and its location to global impacts (Paavola, 2008; Wu et al., 2010). The second deals with issues related to risks and natural disasters and their correlation with vulnerability and resilience, being incorporated into emergency management and risk mitigation (Ahmed et al., 2009; Eakin and Luers, 2006). It can also be said that the first line of research emphasizes environmental relations in the configuration of vulnerable areas, while the second focuses on the social aspects in the formation of vulnerable social groups. There is a consensus between the two approaches to the concept of composition, which is headed by exposure of the elements (local, community) susceptibility and response (adaptability or resilience), which requires measures and representations based on both approaches research, environmental and social since

30 they complement each other. In Brazil, it is common to treat the development of vulnerability indicators in an attempt to assess the social and environmental inequalities in order to reduce the risks associated with natural events, as explained by (Eakin and Luers, 2006).

Vulnerability rates analysis can be based on a set of indicators that are useful for the study of trends and explore conceptual models due to the flexibility and to apply on different scales (Gbetibouo et al., 2010). However, the use of indicators becomes 
Nat. Hazards Earth Syst. Sci. Discuss., https://doi.org/10.5194/nhess-2017-377

Manuscript under review for journal Nat. Hazards Earth Syst. Sci.

Discussion started: 21 November 2017

(c) Author(s) 2017. CC BY 4.0 License.
Natural Hazards

and Earth System

Sciences

Discussions

(c) (i)

restricted by the lack of information about how their variables were chosen and the rules established to determining the vulnerability index of a particular region or community (Luers et al., 2003). These limitations led Kienberger et al., (2009) to work with statistical tools and correlate vulnerability of crops to drought with socioeconomic indicators in order to identify factors that make regions more vulnerable.

5 In this context, the objective of this study is to verify the potential of the local agriculture vulnerability in the NEB specifically to be calculated an indicator of agricultural vulnerability, which will be used precipitation and produce data from various crops, which will serve as tool diagnostics to mitigate impacts due to occurrence of extreme precipitation events in NEB. In item 2 the methodology and the study area will be described, the climatic risk using the SPI and 1991-2010 drought indicators was calculated, the agricultural sensitivity indicator used data from several crops during 1990-2010 and, finally, indicator of

10 adaptability that used data from the Ministry of Social Integration. In Section 3 presents the results and the discussion of the calculated indicators and, finally, item 4 the findings of the study.

\section{Methodology}

\subsection{Study area}

The NEB comprises nine states of the Brazilian federation comprising an area of approximately $1.6 \mathrm{million}^{\mathrm{km}}{ }^{2}$. The region

15 is located the equatorial belt featuring a typical pluviometry variability of these regions. To Alvares et al., (2013) in NEB two types of climate prevail, tropical and semiarid, the tropical climate in NEB is classified in Af (no dry season), Aw (dry winter) and As (dry summer). The semi-arid climate that has the savanna biome affecting all the states of the NEB, the largest portions are in the states of Rio Grande do Norte (61.2\%) and Pernambuco (61.7\%), the total annual precipitation in this region can be less than $700 \mathrm{~mm}$, and presents an average high temperature. Due to the high spatial and temporal variability of precipitation

20 in the region some studies seek to characterize extreme precipitation events, for example, Oliveira et al., (2014) diagnosed that in the autumn months where there are events of high intensity precipitation suggesting an increase of amplitude and precipitation seasonality. Furthermore Oliveira et al., (2013) determined that the central part of the NEB rainy season is from December to May and towards the east from March to July. The precipitation data were provided by the National Water Agency (ANA), the analysis period was from 1 January 1979 to 31 December 2008, this database were used for the study,

25 (Oliveira et al., 2013; Oliveira et al., 2014). Figure 1 shows the study area and used pluviometry stations (red dots).

\subsection{Methods}

The methodology is based on the proposal Kienberger et al., (2009) where the concept of vulnerability is applied in order to diagnose most likely areas in a positive way or not, climate change, affecting various segments of a society.

$\mathrm{V}=\mathrm{f}(\mathrm{H}, \mathrm{S}, \mathrm{AC})$

30 The data used and source are displayed in table 1 and cited throughout the text. Vulnerability function can be described as follows:

In Equation 1, the definition of vulnerability is measured by risk or danger $(\mathrm{H})$ to a physical event that a society or community is exposed; the sensitivity (S), is the degree to which the system is affected, positively or negatively before the stressful event; 
Nat. Hazards Earth Syst. Sci. Discuss., https://doi.org/10.5194/nhess-2017-377

Manuscript under review for journal Nat. Hazards Earth Syst. Sci.

Discussion started: 21 November 2017

(c) Author(s) 2017. CC BY 4.0 License.
Natural Hazards

and Earth System

Sciences

Discussions

(c) (i)

the adaptability (AC) is the answer to how the community can face these events (mitigation). According to Kienberger et al., (2009) the first term of Equation 1 can be very difficult to measure due to lack of biophysical and socioeconomic data in poor areas but can be written in terms of a specific danger (drought, flood, erosion areas, etc.). In this study, unlike the author the climatic risk to agricultural production factor was determined using the SPI and drought records, the degree of vulnerability

5 agricultural is directly related to the frequency of the event and its magnitude.

In the (IPCC, 2014), define that the sensitivity the way that society or community is affected by climate change, suggesting that the degree of impact is driven by risk and mitigated by the ability to adapt. In this work, we characterize the sensitivity through the rural production data, especially for small producers. According to Paavola, (2008) the sensitivity is related to community susceptibility with the risk and this sensitivity can be socio-economic, biophysical feature, among others.

10 Furthermore, the climate attribute is correlated whit the local conditions where communities live and confront such stress. To Eakin and Luers, (2006), the amount of water retained in the soil during the drought period is the sensitivity factor, therefore the amount produced of agricultural products is the sensitivity. This way the SPI can be considered as sensitivity factor to extreme precipitation.

In agreement with Kienberger et al., (2009) the definition of adaptive capacity and resilience are very similar in this way to

15 adopt a term or another is the author's criteria. The definition of adaptive capacity is how much the system can confront and respond positively to submitted stress. Resilience is the system's ability to restore its functions and properties before impact or pressure occurred, it is directly connected to strategic areas in which the national government acts as the educational system and the technological and economic sectors. The function that describes the adaptive capacity (AC) is:

$\mathrm{AC}=\mathrm{f}(\mathrm{SC}, \mathrm{R})$

20 where SC is social capacity, which this study is linked to the core of the Semi-Arid Articulation (ASA), which aims to improve coexistence with water deficit that is outstanding in the region. Resilience (R) is the level of technology and socioeconomic aspects applied by farmers, which is basically characterized by irrigation systems.

\subsubsection{Determination of agricultural productivity sensitivity factor to extreme climate}

25 For the statistical analysis R software (R Core Team, 2013). To create the index sensitivity of agricultural productivity (SEA) used the factor analysis technique applied to the data set containing information of the production characteristics: crops (temporary and permanent), extractive activities (plant and animal), established by IBGE. The agricultural productivity data period is from 1990 to 2010 in a way that was divided into two sampling periods, P1 (1990-1999) and P2 (2000-2010). This technique is widely used in studies to determine the vulnerability in several areas of knowledge such as: climate vulnerability

30 Paavola, (2008); Agricultural vulnerability (Luers et al., 2003; O’Brien et al., 2004). The main purpose of factor analysis is to reduce the number of variables and build based on estimated factors, new variables with very near degree of variability in relation to the original variables. This is important to identify which features are really needed in the definition of vulnerability to climatic extremes and productive areas, which can be influenced by these changes. 
Nat. Hazards Earth Syst. Sci. Discuss., https://doi.org/10.5194/nhess-2017-377

Manuscript under review for journal Nat. Hazards Earth Syst. Sci.

Discussion started: 21 November 2017

(c) Author(s) 2017. CC BY 4.0 License.
Natural Hazards 응

and Earth System

Sciences

Discussions

(c) (i)

Based on Hair Jr et al., (2009) the use of factor analysis is recommended for set of continuous or discrete variables. On the adequacy of the data method the correlation matrix must present values greater than 0.30; Kaiser-Meyer-Olklin (KMO) test is between 0 and 1, being desirable values closest to 1. Hair Jr et al., (2009) suggest 0.50 as an acceptable. Finally, statistical Bartlett or Bartlett sphericity test (BTS) considers null hypothesis (Ho) the matrix of correlation between variables is an identity

5 matrix, meaning they are uncorrelated variables for $\mathrm{p}<0,05$.

\subsubsection{Determining the exposure factor to extreme drought}

To build exposure factor to drought (S) were used monthly precipitation data managed by the National Water Agency-ANA (http://www.ana.gov.br) for the period between 1980 and 2011; as well as disaster data cataloged by Brazil's Civil Defense

10 from 1990 to 2010, which is available in the University Center for Studies and Research on Disaster-CEPED (http://www.ceped.ufsc.br/). Based on the precipitation data was calculated drought climate indicator (SPI) proposed by (Mckee et al., 1993). The magnitude of drought (MD) during the rainy season was calculated according to:

$\mathrm{MD}=\sum_{\mathrm{j}=1} \mathrm{SPI}_{\mathrm{ij}}, \mathrm{j}=1,2,3,4$

being: $j$ the month of the beginning of the rainy season, $i$ the year.

15 Although the research does not include a very important variable in the risk analysis, soil moisture content Mckee et al., (1993) due to the lack of quality data (faults and a good temporal scale) in the selected stations of the selected stations. The rainfall quality in the rainy season in the NEB represents regional socioeconomic development

The second stage to obtain the $\mathrm{S}$ was based on the average number of two types of extreme weather related to disasters cataloged by the civil defense, creating a composite indicator of drought as shown:

$20 \quad \mathrm{IC}_{\mathrm{s}}=\mathrm{I}_{\mathrm{s}}-\left(\mathrm{I}_{\mathrm{B}}+\mathrm{I}_{\mathrm{G}}\right)$

where: $I_{S}$ is the drought indicator; $I_{B}$ is the indicator of sudden flooding and $I_{G}$ is the indicator of gradual flood.

Properly calculated the MD and ICs it was used geographic information software (GIS) for construction and combination of both indicators generating the $\mathrm{S}$ or susceptibility to drought, then the indicator risk or susceptibility to drought (H) is:

$\mathrm{H}=\log \left(\mathrm{MD} * \mathrm{IC}_{\mathrm{S}}\right)$

\section{2.2.3 Determining the adaptive capacity factor to extreme drought}

In this study, the number of establishments using irrigation system (Ni) represents the physical capital. This factor is interesting because it is directly linked to the availability of the natural resource, being inserted into the socioeconomic context and the technology used, since productivity is related to the method and efficiency of the irrigation system (Samaniego et al., 2013).

30 Another indicator that represents the social sphere or a government response front of the extreme event is the federal project on combating drought the Semi-Arid Articulation (ASA) that is to build boards cisterns to capture rainwater, available at link: http://aplicacoes.mds.gov.br/sagi/mi2007/tabelas/mi_social.php . Thereby the number of cisterns in the micro region (Nc) for the low-income population at risk. With these data, we defined averages for each micro region of the Northeast as the expression below: 
Nat. Hazards Earth Syst. Sci. Discuss., https://doi.org/10.5194/nhess-2017-377

Manuscript under review for journal Nat. Hazards Earth Syst. Sci.

Discussion started: 21 November 2017

(c) Author(s) 2017. CC BY 4.0 License.

(c) (i)

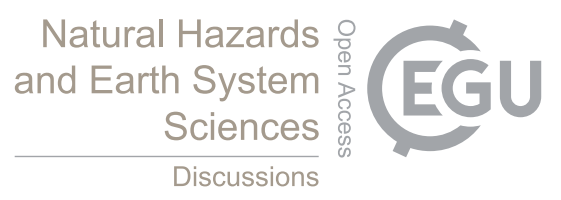

$A C=\frac{\left(N_{C}+N_{i}\right)}{1.000}$.

After calculating each function component $V$ shown in Equation 1 and the use of (GIS) we can visualize and diagnose areas with higher agricultural vulnerability. Considering that the variables used include two levels suggested by the literature, which would be a minimal government action (adaptation) and technology involved to face the dangerous event (resilience).

5 According to the IPCC, (2014) the difference between them is that adaptation is related to the preparation front of the stressful event and resilience are the ways that the various areas of society facing the dangerous event is usually connected to the socioeconomic characteristics and political actions used to combat the stress factor (Cardona, 2003; Silva and Azevedo, 2011).

\section{Results and discussion}

\section{3.1 Exposure the extreme climate and adaptability agricultural.}

The rainfall parameter is quite variable across NEB, due to various atmospheric phenomena scale space-time, and topographical features. According to Oliveira et al., (2014) just to the east coast of the region has two rainy different quarters. The first occurs in the summer (December to February) and the second in the winter (June to August). Therefore, in general, to determine the susceptibility or exposure climate used the data of precipitation NEB of ANA, initially to select the rainy

15 season in the region (Figure 2), corresponding to the climatology of monthly precipitation in the period from 1980 to 2011 . It was observed that the rainy season is from January to April. The main active weather system in that period is the Intertropical Convergence Zone (ITCZ), as it is further south about 2 and $4^{\circ}$ between the months February to April (Rao et al., 2015).

Figure 3 shows o risk of drought according to eq. 6, although the equation considers the non-existence of risk, there is no risk in climate studies. In this way, the east coast the NEB and the state of Maranhão has a very low risk the central zone presents

20 an extreme risk of drought $(1,66-2,27)$. In the semiarid region, the risk in the middle range $(0,76-1,37)$ to high $(1,37-1,66)$ this result corroborates with Rao et al., (2015) that when analyzing the precipitation climatology presents the lowest values of precipitation ranging from 300 to $600 \mathrm{~mm}$. This result agrees with Hay and Mimura, (2006) that determined a similar area with high values of socio-climatic vulnerability indicator SCVI.

Regions where AC presents values between low $(-0,001-0,06)$ and regular $(0,06-0,24)$ throughout the east coast range that

25 goes from the states of Bahia to Rio Grande do Norte; AC presents this characteristic in western NEB covering practically the entire state of Maranhão and part of Piauí. The northeastern semi-arid region presents values between high to extreme AC, mainly in the Midwest of the NEB covering the states of Bahia, Pernambuco and Ceará.

Also in Figure 3 is the spatialization of the adaptive capacity (CA) whose methodology was described in Eq. 6. Considering that the variables used included two levels suggested by the literature Hay and Mimura, (2006) which would be minimal

30 government action (adaptation) and technology involved to cope with the dangerous event (resilience). According to the Oliveira et al., (2013), the difference between the two is that adaptation is related to the preparation for the stressor event and resilience are the means that the various areas of a society face the dangerous event is usually linked to socioeconomic and Policy actions employed to combat the stress factor (Cardona, 2003; Samaniego et al., 2013). 
Nat. Hazards Earth Syst. Sci. Discuss., https://doi.org/10.5194/nhess-2017-377

Manuscript under review for journal Nat. Hazards Earth Syst. Sci.

Discussion started: 21 November 2017

(c) Author(s) 2017. CC BY 4.0 License.

\subsection{Application of factor analysis, sensitivity characterization agriculture and vulnerability}

The set data of agricultural productivity was obtained from the Brazilian Institute of Geography and Statistics - IBGE, from the average of two periods P1 and P2. Since the data is available in different units of measurement, were standardized and R

5 was used to fill the gaps for each specified category and subsequent application of AF. This way, the data filling process was carried out ten times, removing the database with KMO (Kaiser-Meyer-Olklin), which is a measure of global adequacy of the sample (Table 2).

In the second simulation were removed the data that showed suitability measure sample (MSA- Measure of Sampling Adequacy) less than 0.50 (Table 3), as recommended by (Hair Jr et al., 2009). The factor analysis aims to reduce the number

10 of original variables in a smaller base of latent data in such a way that this new base represents the entire variability of the original data, the test indicating the level of data explanation from the factors found in the factor analysis in KMO as well as the MSA. Thereby the first simulation refers to the gap filling in the original database. The test indicated that P1 showed better KMO with value of 0.484 indicating a low explanatory power of the factors and variables. On the other hand, the second simulation the variables that showed MSA below 0.5 were removed, the KMO improved its value reaching 0.578. The gap

15 filling procedure and withdrawal of variables with inappropriate MSA improves the result of factor analysis.

Bartlett sphericity test (BTS) is another test evaluated that indicates the existence of a satisfactory ratio between the factors and variables after analysis application. $5 \%$ of significance level is considered for the test. Therefore, in Table 2 all BTS values show statistical significance in both simulations. The construction of the factorial model was based on P1 sample.

The commonality is the proportion of variance of a shared variable with the common factors in factor analysis; Table 3 shows

20 the P1 values with MSA and commonalities after the extraction of factors. Note that all variables have values above 0.5 MSA. Other important factor are the commonalities. After the extraction of the factors all increased. Variables that showed commonality above 0.7 after the extraction of factors were the arboreal cotton, watermelon, tomato and firewood and the values are respectively $0.774 ; 0.825 ; 0.638$ and 0.653 .

Knowing that these coefficients representing the correlation between factor and attribute (Table 4), can observe that the first

25 factor is highly correlated with watermelon and its value is 0.938 . Considering for the study the loads with value of 0.6 at a minimum, although O'Brien et al., (2004) recommend 0.4. The second factor is highly correlated with arboreal cotton. The third factor has a coefficient of 0.742 for firewood. The variable with the highest value for the factor 4 is tomato 0.802 and finally for factor 5 orange 0.667 .

This AF has a total variance of $42 \%$ for the five factors compared suggested by O'Brien et al., (2004) the estimated values are

30 relatively low. Despite the factor model needs adjustment, it will be composed of five factors that are also called latent variables and represented segments of the agricultural production chain. Thereby the 1 st factor represented by fruit-export, the main producing states are: Bahia, Ceará, Pernambuco and Rio Grande do Norte Torres et al., (2012); the 2nd factor represented by the rainfed crop, such as cotton which have specific water requirements, this way it needs a proper irrigation system or rain in specific phenologic periods, otherwise the production will be compromised (Nelson et al., 2010). 
Nat. Hazards Earth Syst. Sci. Discuss., https://doi.org/10.5194/nhess-2017-377

Manuscript under review for journal Nat. Hazards Earth Syst. Sci.

Discussion started: 21 November 2017

(c) Author(s) 2017. CC BY 4.0 License.
Natural Hazards

and Earth System

Sciences

Discussions

(c) (i)

The environmental impact or anthropogenic effect is highlighted on 3rd factor, deforestation in the caatinga region for supply of raw materials, mainly ceramics and charcoal industries Vidal and Ximenes, (2016) on the other hand, the 4th factor is characterized for products intended for agribusiness food. Tomatoes are the base of many food industries (soup, sauce, juice, etc.) with a significant increase in the consumer market, especially fast-food. The states of Pernambuco and Bahia produces

5 about $11 \%$ of the national output of tomatoes, according to the Inter-Union Department of Statistics and Socioeconomic Studies (Silva et al., 2012). Finally, the 5th factor is characterized by citrus production, where its production has a great importance in the scenario mentioned above in the 4th factor, over $90 \%$ of production is in the Northeastern states of Bahia and Sergipe according to the Brazilian Company Agricultural Research-EMBRAPA (http://sistemasdeproducao.cnptia.embrapa.br/FontesHTML/Citros/CitrosNordeste/).

10 To construct the factor model, we calculated the factor sensibility agricultural (S) for each period. The result is represented in Figure 4. Are observed in a few areas of low sensitivity values. The largest areas are the northwestern region comprising the states of Maranhão and Piauí. In the southern region, the values ranging from moderate sensitivity to extreme, with areas covering the southern part of Piauí and Bahia. In the northern, there is a stratification in the $S$ values ranging from low to moderate. In eastern ranges from regular too high. In Figure 4, referring to P2, there is a change in the pattern of $S$, highlighting

15 the northwestern region ranging from low to high and the east of Bahia with low values of $S$, unlike Figure 4a these areas had values ranging from moderate the high, indicating there was an increase in agricultural production in these areas, which suggests that producers have had technical guidance and technology investments.

Finally Figure 5 shows the characterization agricultural vulnerability (V), Figure 5 (left) was observed that the most vulnerable areas are in south-central NEB region, comprising almost all of state of Bahia, the states of Alagoas, Sergipe and part of

20 Pernambuco presenting high $V$ values. Moreover, northwest and north NEB sectors presented $V$ ranging from low to moderate. In Figure 5(right) the extreme west of the NEB deserves to be highlighted, the $V$ in this area is considered low; in Figure 5(left) was classified with extreme $V$.

South of Bahia area presented low $A C$ and $H$, when computed $V$ presented extreme classification for the area, a fact that this area has the lowest AC due to possess a smaller number of tankers built by SIGA-ASA program and downs producers who

25 have access to irrigation, in this way presenting higher $V$. This result is similar to those reported by R Core Team, (2013) considered in his research, the adaptive capacity of a social nature as a variable, such as: health, communication, education and technology.

\section{Conclusion}

30 The results show that the NEB has degrees of agricultural vulnerability (V) between regular and high relative to the 2000 census, mainly in the southern region, which comprises the state of Bahia. In addition, the risk of drought $(\mathrm{H})$ is very high, especially in the central part of the NEB. 
Nat. Hazards Earth Syst. Sci. Discuss., https://doi.org/10.5194/nhess-2017-377

Manuscript under review for journal Nat. Hazards Earth Syst. Sci.

Discussion started: 21 November 2017

(c) Author(s) 2017. CC BY 4.0 License.
Natural Hazards

and Earth System

Sciences

Discussions

Considering that the AC factor showed that the semi-arid region of the Northeast has a highly adaptive classification, considering the variables used, so that it can be improved by including a greater number of sociodemographic variables. Faced with the concept of agricultural vulnerability to extremes of drought adopted in the research the main conclusions are:

1. There are areas where the risk of drought does not exist, evidenced in the range of the east coast that goes from the state of Bahia to Paraíba, and the extreme west that comprises almost every state of Maranhão;

2. About SeA, the P1 presented greater statistical significance when applied to the factorial model, whose explained variance is $42 \%$ considered low, but represents the productive chain of the region;

3. Regarding adaptive capacity, the study shows that the NEB presents between a medium and extreme adaptation $(0,24-5,42)$, it is necessary to analyze the broader socioeconomic characteristics, such as educational level of producer;

4. In the scope of risk analysis the NEB presents the central range, where a large part of the northeastern semi-arid region is located $(0,76-2,26)$, and the vulnerability pattern $\mathrm{V}$, besides showing an improvement in $\mathrm{P} 2$, values were generally good, reinforcing that during the period there was an improvement in production, justified by the $\mathrm{SeA}$ of $\mathrm{P} 2$ and the $\mathrm{AC}$ adopted in the research.

5. With this, the NEB has an average agricultural vulnerability in P1 and there has been an improvement in P2..

Acknowledgments The authors thank the agencies that provided the data: ANA, CEPED, IBGE and the Coordination for the Improvement of Higher Education Personnel (CAPES) to grant the postdoctoral fellowship to the first author.

\section{References}

Ahmed, S. a, Diffenbaugh, N. S. and Hertel, T. W.: Climate volatility deepens poverty vulnerability in developing countries, Environ. Res. Lett., 4(3), 8, doi:10.1088/1748-9326/4/3/034004, 2009.

Alvares, C. A., Stape, J. L., Sentelhas, P. C., Gonçalves, J. L. D. M. and Sparovek, G.: Köppen's climate classification map for Brazil, Meteorol. Zeitschrift, 22(July 2015), 711-778, doi:10.1127/0941-2948/2013/0507, 2013.

25 Antwi-Agyei, P., Fraser, E. D. G., Dougill, A. J., Stringer, L. C. and Simelton, E.: Mapping the vulnerability of crop production to drought in Ghana using rainfall, yield and socioeconomic data, Appl. Geogr., 32(2), 324-334, doi:10.1016/j.apgeog.2011.06.010, 2012.

Barata, M. M. de L. and Confalonieri, U. E. C.: População do estado do Rio de Janeiro aos impactos das mudanças climáticas nas áreas social, saúde e ambiante, Belo Horizonte., 2011.

30 Cardona, D. O.: The Need for Rethinking the Concepts of Vulnerability and Risk from a Holistic Perspective : A Necessary Review and Criticism for Effective Risk Managment, in Mapping Vulnerability: Disasters, Development and People, London., 2003. 
Nat. Hazards Earth Syst. Sci. Discuss., https://doi.org/10.5194/nhess-2017-377

Manuscript under review for journal Nat. Hazards Earth Syst. Sci.

Discussion started: 21 November 2017

(C) Author(s) 2017. CC BY 4.0 License.
Natural Hazards

and Earth System

Sciences

Discussions

(c) (i)

Castro, A. L. C. de, Calheiros, L. B., Cunha, M. I. R. and Bringel, M. L. N. da C.: Manual de desastres: desastres naturais, Brasilia., 2003.

Eakin, H. and Luers, A. L.: Assessing the Vulnerability of Social-Environmental Systems, Annu. Rev. Environ. Resour., 31(1), 365-394, doi:10.1146/annurev.energy.30.050504.144352, 2006.

5 Ford, J. D., Smit, B., Wandel, J. and MacDonald, J.: Vulnerability to climate change in Igloolik, Nunavut: what we can learn from the past and present, Polar Rec. (Gr. Brit)., 42(2), 127, doi:10.1017/S0032247406005122, 2006.

Gbetibouo, G. a., Ringler, C. and Hassan, R.: Vulnerability of the South African farming sector to climate change and variability: An indicator approach, Nat. Resour. Forum, 34(3), 175-187, doi:10.1111/j.1477-8947.2010.01302.x, 2010.

Hair Jr, J. F., Black, W. C., Babin, B. J. and Anderson, R. E.: Multivariate Data Analysis, 7th ed., Prentice Hall., 2009.

10 Hay, J. and Mimura, N.: Supporting climate change vulnerability and adaptation assessments in the Asia-Pacific region: an example of sustainability science, Sustain. Sci., 1(1), 23-35, doi:10.1007/s11625-006-0011-8, 2006.

Ibarrarán, M. E., Ruth, M., Ahmad, S. and London, M.: Climate change and natural disasters: macroeconomic performance and distributional impacts, Environ. Dev. Sustain., 11(3), 549-569, doi:10.1007/s10668-007-9129-9, 2007.

IPCC: Summary for policymakers., in Climate Change 2014: Impacts,Adaption, and Vulnerability.Part A: Global and Sectoral

15 Aspects., edited by D. J. Dokken, C. B. Field, V. . Barros, M. . Mach, and A. Et, pp. 1-32, Cambridge. [online] Available from: http://ipcc-wg2.gov/AR5/images/uploads/WG2AR5_SPM_FINAL.pdf, 2014.

Karim, M. and Mimura, N.: Impacts of climate change and sea-level rise on cyclonic storm surge floods in Bangladesh, Glob. Environ. Chang., 18(3), 490-500, doi:10.1016/j.gloenvcha.2008.05.002, 2008.

Kienberger, S., Lang, S. and Zeil, P.: Spatial vulnerability units - expert-based spatial modelling of socio-economic

20 vulnerability in the Salzach catchment, Austria, Nat. Hazards Earth Syst. Sci., 9(3), 767-778, doi:10.5194/nhess-9-767-2009, 2009.

Lee, Y.-J.: Social vulnerability indicators as a sustainable planning tool, Environ. Impact Assess. Rev., 44, 31-42, doi:10.1016/j.eiar.2013.08.002, 2014.

Luers, A. L., Lobell, D. B., Sklar, L. S., Addams, C. L. and Matson, P. A.: A method for quantifying vulnerability, applied to

25 the agricultural system of the Yaqui Valley, Mexico, Glob. Environ. Chang., 13(4), 255-267, doi:10.1016/S09593780(03)00054-2, 2003.

Mckee, T. B., Doesken, N. J. and Kleist, J.: The relationship of drought frequency and duration to time scales, , (January), 1722, 1993.

Nelson, G. C., Rosegrant, M. W., Palazzo, A., Gray, I., Ingersoll, C., Robertson, R., Tokgoz, S. and Zhu, T.: Food Security,

30 Farming, and Climate Change to 2050: Scenarios, Results, Policy Options, International Food Policy Research Institute, Washington., 2010.

O’Brien, K., Leichenko, R., Kelkar, U., Venema, H., Aandahl, G., Tompkins, H., Javed, A., Bhadwal, S., Barg, S., Nygaard, L. and West, J.: Mapping vulnerability to multiple stressors: climate change and globalization in India, Glob. Environ. Chang., 14(4), 303-313, doi:10.1016/j.gloenvcha.2004.01.001, 2004. 
Nat. Hazards Earth Syst. Sci. Discuss., https://doi.org/10.5194/nhess-2017-377

Manuscript under review for journal Nat. Hazards Earth Syst. Sci.

Discussion started: 21 November 2017

(c) Author(s) 2017. CC BY 4.0 License.
Natural Hazards

and Earth System

Sciences

Discussions

(c) (i)

Oliveira, P. T., Lima, K. C. and Santos e Silva, C. M.: Synoptic environment associated with heavy rainfall events on the coastland of Northeast Brazil, Adv. Geosci., 35, 73-78, doi:10.5194/adgeo-35-73-2013, 2013.

Oliveira, P. T. De, Santos, C. M. and Lima, K. C.: Linear trend of occurrence and intensity of heavy rainfall events on Northeast Brazil, Atmos. Sci. Lett., 177(December 2013), 172-177, doi:10.1002/as12.484, 2014.

5 Paavola, J.: Livelihoods, vulnerability and adaptation to climate change in Morogoro, Tanzania, Environ. Sci. Policy, 11(7), 642-654, doi:10.1016/j.envsci.2008.06.002, 2008.

R Core Team: R: A language and environment for statistical computing. R Foundation for Statistical Computing, , 2, doi:3900051-07-0, 2013.

Rao, V. B., Franchito, S. H., Santo, C. M. E. and Gan, M. A.: An update on the rainfall characteristics of Brazil : seasonal

10 variations and trends in 1979 - 2011, Int. J. Climatol., 36, 291-302, doi:10.1002/joc.4345, 2015.

Samaniego, L., Kumar, R., Zink, M., Samaniego, L., Kumar, R. and Zink, M.: Implications of Parameter Uncertainty on Soil Moisture Drought Analysis in Germany, J. Hydrometeorol., 14(1), 47-68, doi:10.1175/JHM-D-12-075.1, 2013.

Sánchez-Cortés, M. S. and Chavero, E. L.: Indigenous perception of changes in climate variability and its relationship with agriculture in a Zoque community of Chiapas, Mexico, Clim. Change, 107(3-4), 363-389, doi:10.1007/s10584-010-9972-9,

152010.

Silva, B. K. N. and Lucio, P. S.: Indicator of Agriculture Vulnerability to Climatic Extremes . A Conceptual Model with Case Study for the Northeast Brazil, Atmos. Clim. Sci., 4(April), 334-345, 2014.

Silva, M. T., Silva, V. D. P. R. and Azevedo, P. V. De: O cultivo do algodão herbáceo no sistema de sequeiro no Nordeste do Brasil, no cenário de mudanças climática Cultivation of upland cotton in the rainfed system in Northeastern Brazil in the

20 climate change scenario, , (83), 80-91, 2012.

Silva, V. D. P. R. and Azevedo, P. V. De: Lisímetro de pesagem de grande porte . Parte II : Consumo hídrico do coqueiro anão verde irrigado Large-scale weighing lysimeter . Part II : Water requirements of the irrigated dwarf-green coconut, , (82), 526$532,2011$.

Simelton, E., Fraser, E. D. G., Termansen, M., Forster, P. M. and Dougill, A. J.: Typologies of crop-drought vulnerability : an empirical analysis of the socio-economic factors that influence the sensitivity and resilience to drought of three major food crops in China ( 1961 - 2001 ), Environ. Sci. Policy, 12, 438-452, doi:10.1016/j.envsci.2008.11.005, 2009.

Tanser, F. C., Sharp, B. and le Sueur, D.: Potential effect of climate change on malaria transmission in Africa., Lancet, 362(9398), 1792-8, doi:10.1016/S0140-6736(03)14898-2, 2003.

Torres, R. R., Lapola, M., D., Marengo, J. a. and Lombardo, M. a.: Socio-climatic hotspots in Brazil, Clim. Change, 115(3-

4), 597-609, doi:10.1007/s10584-012-0461-1, 2012.

Tubi, A., Fischhendler, I. and Feitelson, E.: The effect of vulnerability on climate change mitigation policies, Glob. Environ. Chang., 22(2), 472-482, doi:10.1016/j.gloenvcha.2012.02.004, 2012.

Vidal, M. D. F. and Ximenes, L. J. F.: Comportamento recente da fruticultura nordestina: área , valor da produção e comercialização, Cad. Setorial ETENE, 1(2), 18-26 [online] Available from: 
Nat. Hazards Earth Syst. Sci. Discuss., https://doi.org/10.5194/nhess-2017-377

Manuscript under review for journal Nat. Hazards Earth Syst. Sci.

Discussion started: 21 November 2017

(c) Author(s) 2017. CC BY 4.0 License.

(c) (i)

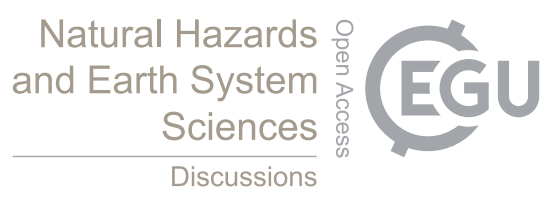

https://www.bnb.gov.br/documents/80223/1138347/3_fruta.pdf/e5f76cc8-c25a-ff08-6402-9d75f3708925, 2016.

Wu, J., He, B., Lü, A., Zhou, L., Liu, M. and Zhao, L.: Quantitative assessment and spatial characteristics analysis of agricultural drought vulnerability in China, Nat. Hazards, 56(3), 785-801, doi:10.1007/s11069-010-9591-9, 2010.

Zhang, L. and Yongfu, Q.: Annual distribution features of precipitation in China and their interannual variations, Acta

5 Meteorol. Sin., 17(3), 146-163, 2003.

10

15 
Nat. Hazards Earth Syst. Sci. Discuss., https://doi.org/10.5194/nhess-2017-377

Manuscript under review for journal Nat. Hazards Earth Syst. Sci.

Discussion started: 21 November 2017

(c) Author(s) 2017. CC BY 4.0 License.

(c) (i)

\section{Natural Hazards and Earth System \\ Sciences \\ Discussions}
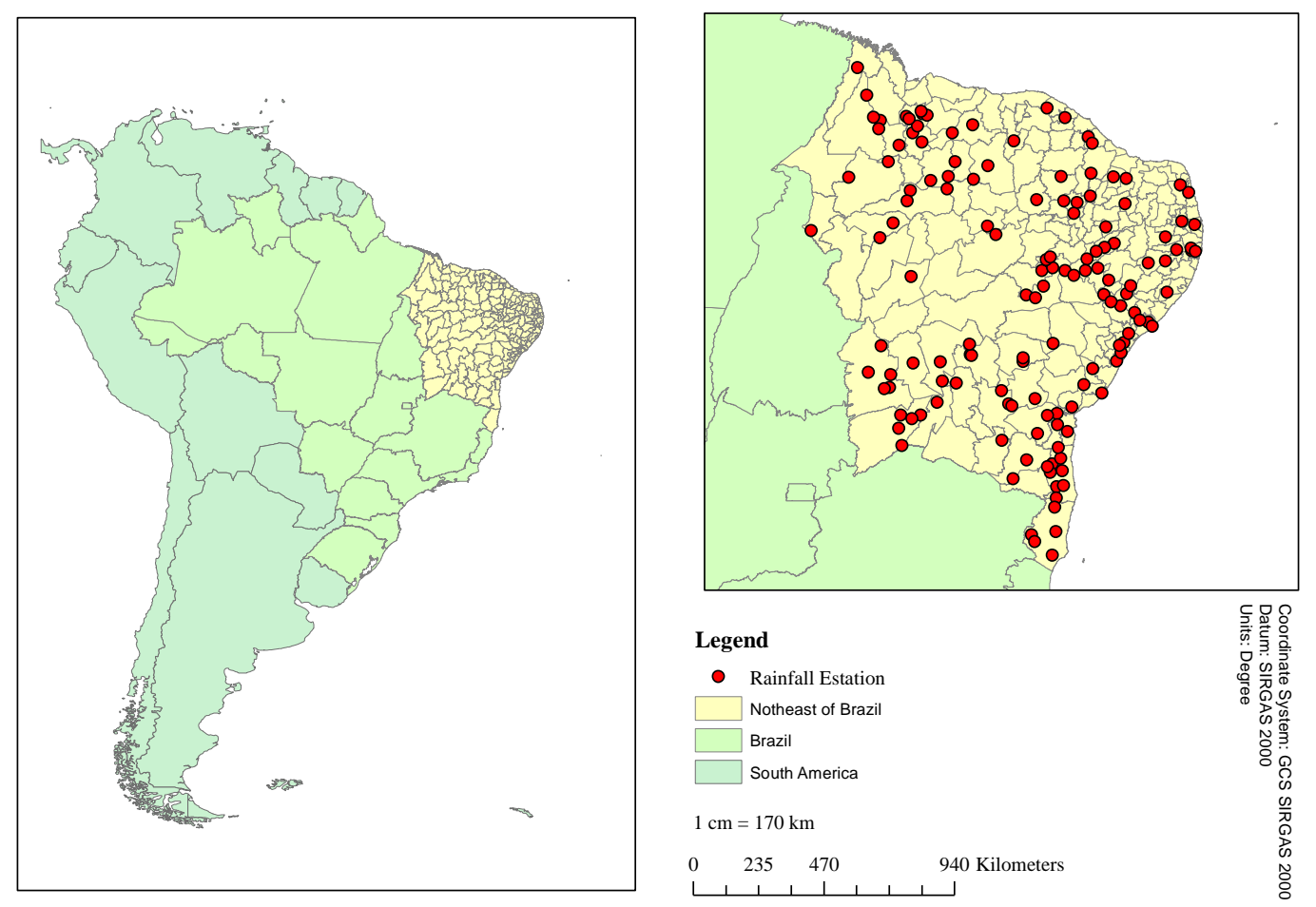

Figure 1: Study area highlighting the political division of the region in micro regions along with the rainfall stations of the National WaternAgency (ANA).

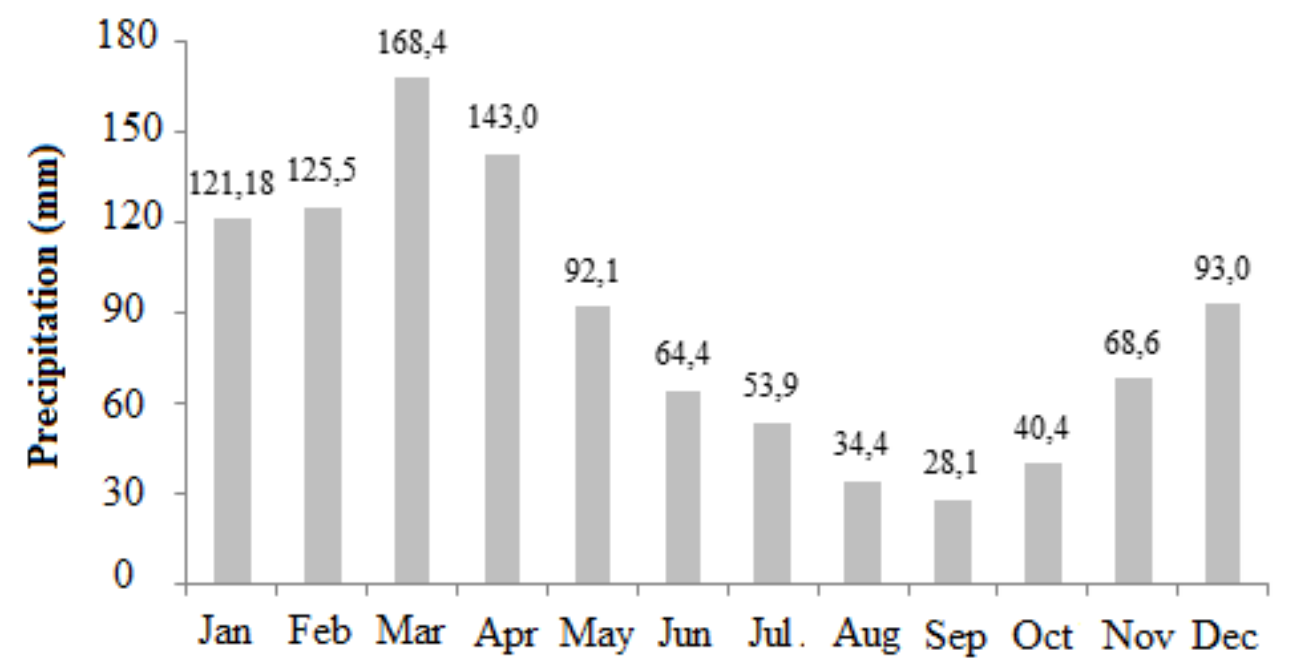

Figure 2. Characterization climate of rainfall in the Northeast of Brazil, during 1980-2011. 
Nat. Hazards Earth Syst. Sci. Discuss., https://doi.org/10.5194/nhess-2017-377 Manuscript under review for journal Nat. Hazards Earth Syst. Sci.

Discussion started: 21 November 2017

(c) Author(s) 2017. CC BY 4.0 License.

(c) (i)
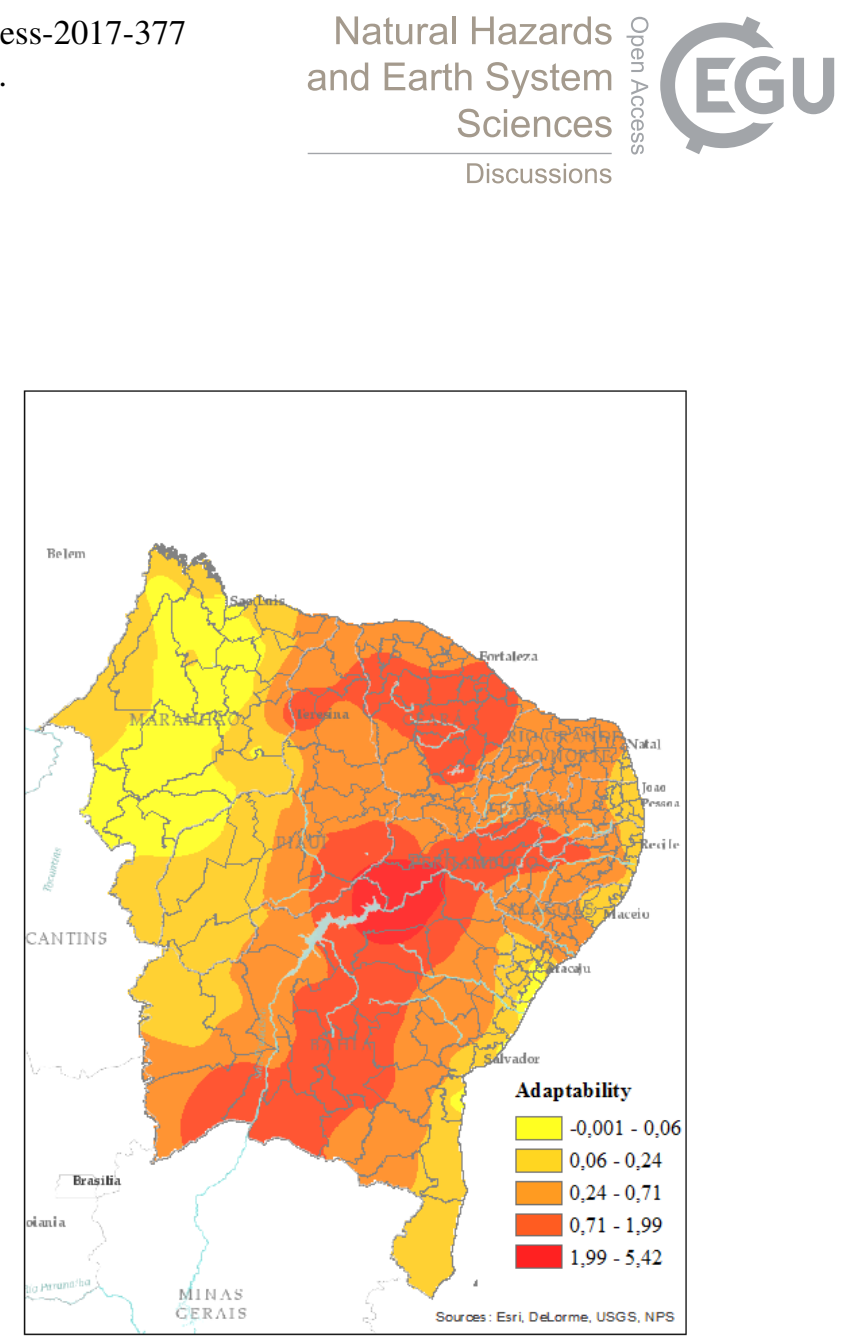

Figure 3. Characterization of susceptibility/risk of drought (left) and spatialization of adaptive capacity (AC) for the Northeast of Brazil. 
Nat. Hazards Earth Syst. Sci. Discuss., https://doi.org/10.5194/nhess-2017-377

Manuscript under review for journal Nat. Hazards Earth Syst. Sci.

Discussion started: 21 November 2017

(c) Author(s) 2017. CC BY 4.0 License.

(c) (i)

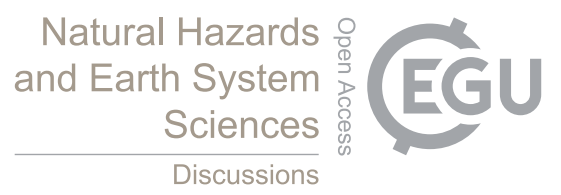

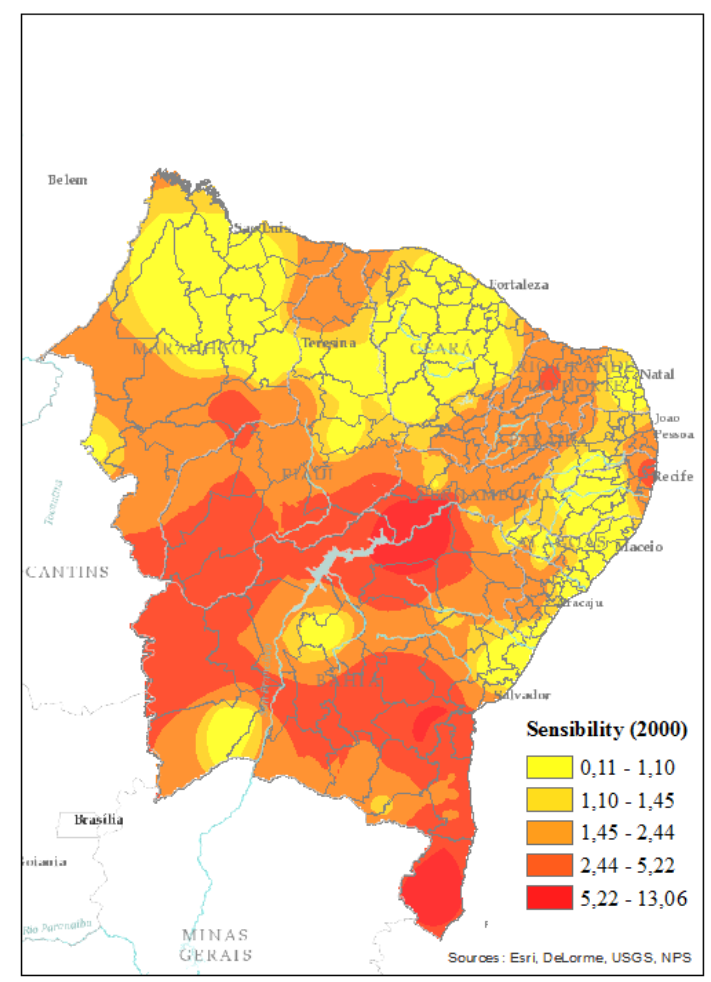

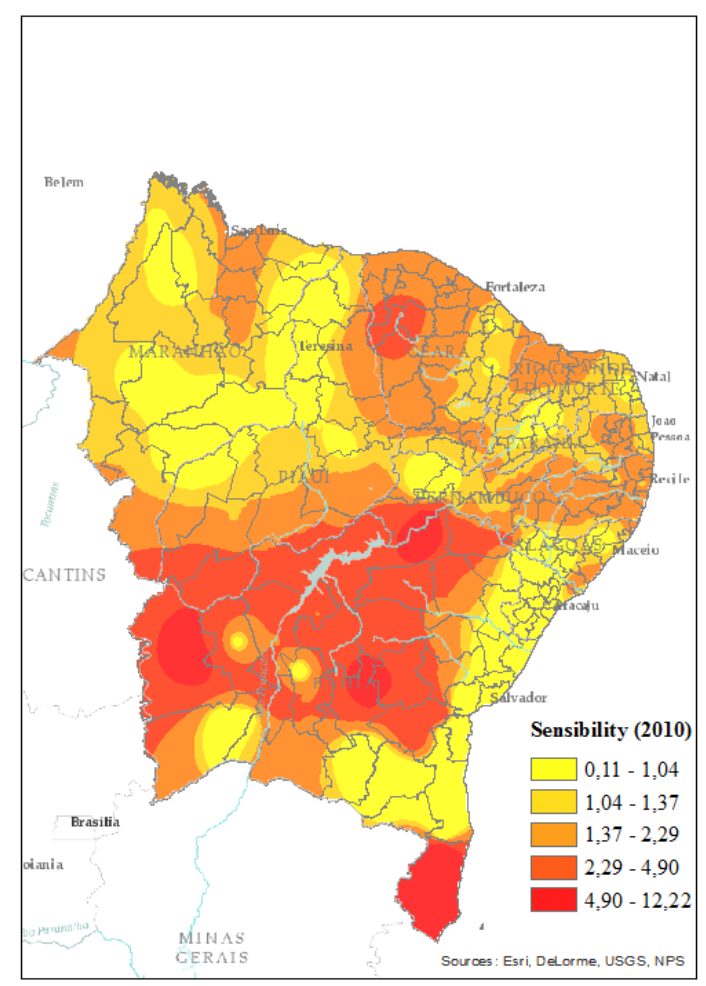

Figure 4. Spatial distribution of agricultural sensitivity indicator to the Northeast of Brazil for the respective periods: 1990-1999 (left) and 2000-2010 (right). 
Nat. Hazards Earth Syst. Sci. Discuss., https://doi.org/10.5194/nhess-2017-377

Manuscript under review for journal Nat. Hazards Earth Syst. Sci.

Discussion started: 21 November 2017

(c) Author(s) 2017. CC BY 4.0 License.

(c) (i)

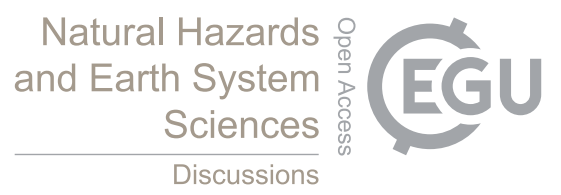

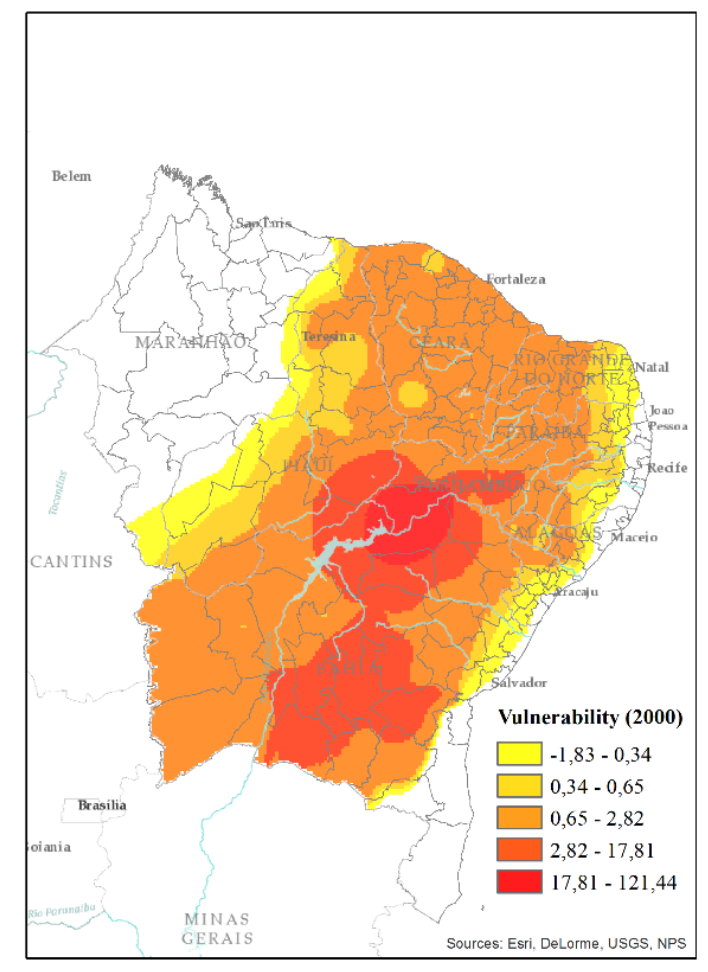

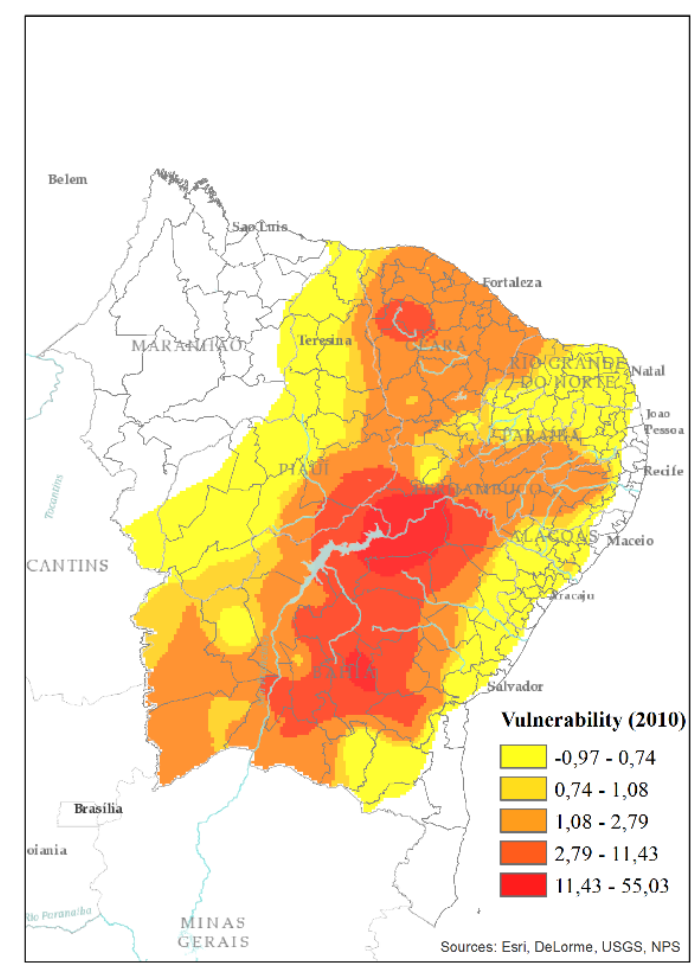

Figure 5. Characterization of the agricultural vulnerability to extreme precipitation for the NEB considering the capacity factor and adaptation. 
Nat. Hazards Earth Syst. Sci. Discuss., https://doi.org/10.5194/nhess-2017-377

Manuscript under review for journal Nat. Hazards Earth Syst. Sci.

Discussion started: 21 November 2017

(c) Author(s) 2017. CC BY 4.0 License.
Natural Hazards and Earth System

Sciences

Discussions

(c) (i)

Table 1. Data used in the study

\begin{tabular}{l|l}
\hline \multicolumn{1}{c|}{ Data } & \multicolumn{1}{c}{ Font } \\
\hline $\begin{array}{l}\text { Precipitation } \\
\text { Water Disasters }\end{array}$ & $\frac{\text { http://www.ana.gov.br }}{\text { http://www.ceped.ufsc.br }}$ \\
$\begin{array}{l}\text { Agricultural Productivity and } \\
\text { Irrigation }\end{array}$ & $\underline{\text { http://www2.sidra.ibge.gov.br/ }}$ \\
Cisterns & http://aplicacoes.mds.gov.br/sagi/mi2007/tabelas/mi_social.php \\
\hline
\end{tabular}

Table 2. Sample adequacy measures such as the Kaiser-Meyer-Olklin test (KMO) Bartlett sphericity test (BTS) and p-value.

\begin{tabular}{cccc}
\hline \multicolumn{3}{c}{$1^{\circ}$ simulation } & \\
\hline Period & KMO & BTS & p-value \\
P1 & 0,484 & 1131,9 & $<0,001$ \\
P2 & 0,462 & 1580,9 & $<0,001$ \\
\hline P1 & $2^{\circ}$ simulation & 0,008 \\
P2 & 0,578 & 488,53 & 0,006 \\
\hline
\end{tabular}

5 Table 3. Sample adequacy measure (MSA), initial and final commonality, relating toP1.

\begin{tabular}{lcc}
\hline \multicolumn{1}{c}{ Variables } & $\begin{array}{c}\text { Sample adequacy } \\
\text { Measure }\end{array}$ & commonalities \\
\hline Cotton arboreal & 0.540 & $\mathbf{0 . 7 7 4}$ \\
Banana & 0.727 & 0.175 \\
Cashew nut & 0.517 & 0.241 \\
Orange & 0.475 & 0.274 \\
Mango & 0.511 & 0.207 \\
Pineapple & 0.678 & 0.407 \\
Herbaceous cotton & 0.558 & 0.251 \\
Sweet potato & 0.597 & 0.169 \\
Sugar cane & 0.505 & 0.305 \\
Broad bean & 0.616 & 0.415 \\
watermelon & 0.592 & $\mathbf{0 . 8 2 5}$ \\
Tomato & 0.599 & $\mathbf{0 . 6 3 8}$ \\
Milk & 0.590 & 0.375 \\
Firewood & 0.561 & $\mathbf{0 . 6 5 3}$ \\
\hline
\end{tabular}


Nat. Hazards Earth Syst. Sci. Discuss., https://doi.org/10.5194/nhess-2017-377

Manuscript under review for journal Nat. Hazards Earth Syst. Sci.

Discussion started: 21 November 2017

(C) Author(s) 2017. CC BY 4.0 License.

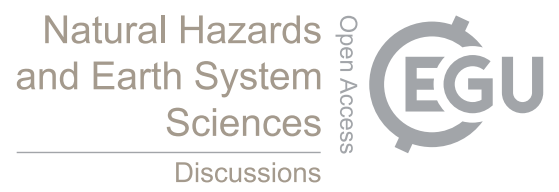

Table 4. Factors observed and their respective proportionate and accumulated variances to set agricultural production.

\begin{tabular}{llllll}
\hline Variables & Factor1 & Factor2 & Factor3 & Factor4 & Factor5 \\
\hline $\begin{array}{l}\text { Cotton arboreal } \\
\text { Banana }\end{array}$ & 0.163 & $\mathbf{0 . 9 1 4}$ & 0.234 & & \\
Cashew nut & & 0.411 & & 0.171 & 0.287 \\
$\begin{array}{l}\text { Orange } \\
\text { Mango }\end{array}$ & & -0.158 & -0.109 & & 0.273 \\
$\begin{array}{l}\text { Pineapple } \\
\text { Herbaceous cotton }\end{array}$ & 0.402 & & -0.147 & 0.266 & \\
Sweet potato & 0.141 & 0.238 & -0.137 & & -0.374 \\
Sugar cane & & 0.486 & -0.143 & & \\
Broad bean & 0.525 & & & & \\
watermelon & $\mathbf{0 . 9 3 8}$ & & 0.136 & 0.228 & \\
Tomato & 0.476 & & & $\mathbf{0 . 8 0 2}$ & 0.154 \\
Milk & 0.231 & 0.119 & 0.382 & & -0.193 \\
Firewood & & & $\mathbf{0 . 7 4 2}$ & 0.115 & \\
\hline Variance proportional & 0.119 & 0.097 & 0.083 & 0.065 & 0.056 \\
\hline Cumulative variance & 0.119 & 0.216 & 0.299 & 0.364 & $\mathbf{0 . 4 2 0}$ \\
\hline
\end{tabular}

